\title{
KONSEP KHUDI IQBAL DALAM PENGEMBANGAN KREATIFITAS PEMBELAJARAN DI MADRASAH
}

\author{
${ }^{1}$ Muhammad Masruri, ${ }^{2}$ Muqowim, ${ }^{3}$ Radjasa \\ 1, 2,3 Universitas Islam Negeri Sunan Kalijaga Yogyakarta \\ ${ }^{1}$ Email: Muhammadmasruri8@Gmail.Com \\ 2 Email: muqowim@uin_suka.ac.id \\ 33Email:radjasa@uin_suka.ac.id
}

\begin{abstract}
Abstrak: Tujuan kajian ini adalah untuk mengontekstualisasikan konsep Khudi dari seorang Muhammad Iqbal dalam pengembangan kreatifitas pembelajaran di Madrasah. peneliti akan mencoba mengawali menelaah biografi dan sejarah pendidikan yang didapat Muhammad Iqbal, konsep Khudi serta pengembangan konsep Khudi tersebut dalam pembelajaran di Madrasah. Metode penelitian yang digunakan adalah metode studi pustaka (library research). Studi kepustakaan adalah tekhnik pengumpulan dataddengan mengadakan studi penelaahan terhadap buku-buku, literatur-literatur, catatan-catatan dan laporan-laporan yang ada hubungannya dengan masalah yang dipecahkan. Jenis penelitian ini adalah termasuk penelitian deskriptif kualitatif. Hasil penelitian menunjukkan bahwa proses pembelajaran di madrasah hendaknya mengutamakan kepribadian dengan mewujudkan keseimbanagn berupa kebahagiaan lahiriah dan batiniah. Muhammad Iqbal (1877-1938) menjadi tokoh sentral dengan berbagai gagasannya sebagai seorang tokoh pemikir dan pembaharu dapat menjadi motor penggerak bagi para pendidik dalam melaksanakan proses pendidikan di madrasah. Dengan gagasan Kbudi-nya, Iqbal memberikan gambaran kepada pendidik di madrasah agar saling melengkapi dan mampu berdialog tidak hanya antara pelaku pendidikan saja melainkan dapat berdialog dengan Tuhan. Hal ini dapat tercapai apabila seorang pendidik dapat mencapai derajat Khudi yang tinggi. Hal ini dapat menjadi pemecah kebuntuan pendidik tatkala menghadapi berbagai macam permasalahan yang timbul dalam menghadapi proses pembelajaran.
\end{abstract}

Kata Kunci: Konsep Khudi Iqbal, Kreatifitas Pembelajaran, Madrasah

Title: Iqbal Concept Of Iqbal In Developing Learning Creativity In Madrasab

Abstract: The purpose of this study is to contextualize the Khudi concept of a Mubammad Iqbal in developing learning creativity in Madrasas. The researcher will try to start studying the biograpby and educational history obtained by Mubammad Iqbal, the Kbudi concept and the development of the Kbudi concept in learning in Madrasas. The research method used is the library study method. Literature study is a data collection technique by conducting a study of books, literature, notes and reports that are related to the problem being solved. This type of research is a qualitative descriptive study. The results showed that the learning process in madrasas should prioritize personality by manifesting balance in the form of physical and inner happiness. Muhammad Iqbal (1877-1938) had became a central figure with his various ideas as a thinker and reformer figure can be a driving force for educators in implementing the education process in madrasas. With his Khudi ideas, Iqbal had given an overview to educators in madrasas so that they are mutually complementary and able to be dialogue not only among education practitioners but also in dialogue with God. This can be achieved if an educator can achieve a high degree of gambling. This can be a deadlock for educators when facing various kinds of problems that arise in dealing with the learning process

Keywords: Educators, Khudi, Muhammad Iqbal, Madrasah 


\section{PENDAHULUAN}

Akhir abad ke delapan belas dan awal abad ke sembilan belas Masehi muncul sebuah gagasan pembaharuan dalam Islam, ditandai salah satunya adalah dengan adanya kontak Islam dengan Barat untuk kedua kalinya. Kontak ini mengakibatkan masuknya budaya dan tekhnologi barat ke dalam dunia Islam. ${ }^{1}$ Umat Islam merasa heran, ketika dahulu bangsa Barat belajar dari umat Islam pada abad ke dua belas dan ketiga belas sekarang sudah jauh dapat melampaui Islam terutama dalam kemajuan bidang ilmu pengetahuan dan tekhnologi. Melihat kondisi tersebut ulama-ulama pada abad ke Sembilan belas merasa tergugah dan memutar otak bagaimana caranya masa kejayaan Islam yang dahulu pernah ada dapat diraih kembali. Akhirnya muncul para pembaharu Islam di Mesir yang mengusung ide dan gagasan baru dalam Islam, diantaranya ada Jamaludin Al-Afghani, Muhammad Abduh, Al-Tantawi, termasuk Muhammad Iqbal dan Ahmad Khan di India. Proses pembaharuan Islam menjadi hal yang urgen bagi perkembangan Islam pasca runtuhnya Baghdad pada masa kejayaannya. Hal ini juga menjadi konsen dari seorang Muhammad Iqbal untuk dapat memberikan kontribusi dalam merealisasikan usaha-usaha dari para ulama untuk memurnikan ajaran Islam dari pengaruh Barat.

Muhammad Iqbal dilahirkan dari keluarga yang taat pada agama. Ayah Muhammad Iqbal, Nur Muhammad, adalah seorang sufi yang zuhud. Nur Muhammad yang pada mulanya bekerja pada dinas pemerintahan dan kemudian beralih menjadi pedagang dikenal sebagai seorang yang shaleh dan relegius, bahkan seorang sufi. Muhammad Iqbal dilahirkan di Sialkot, Punjab, India (sekarang termasuk wilayah pakistan) pada 9 November 1877 Masehi, bertepatan pada tanggal 3 Dzul Qa'dah. Begitu juga dengan Ibu Muhammad Iqbal, Imam Bibi adalah seorang wanita yang solihah dan taqwa. Pendidikan dasar Muhammad Iqbal diperoleh langsung dari ayahnya, Nur Muhammad. Sedangkan di surau/mushola, beliau mempelajari ilmu agama, Al-Qur'an dan menghafalkannya. Pendidikan formal Muhammad Iqbal dimulai di Scottish Mission School di Sialkot. Beliau yang pada saat itu masih dalam usia remaja telah memperoleh bimbingan yang sangat berarti dan diketahui kecerdasannya oleh gurunya yang bernama Maulana Mir Hasan, seorang ahli dalam bahasa Persia dan Arab, yang juga teman ayahnya, Nur Muhammad. ${ }^{2}$ Setelah menyelesaikan pendidikannya di Sialkot, pada tahun 1895 Muhammad Iqbal yang cerdas dan mempunyai bakat sebagai penyair hijrah ke Lahore untuk melanjutkan studinya di Governtment College sampai beliau berhasil memperoleh gelar B.A pada tahun 1897. Iqbal kemudian melanjutkan belajarnya dan mengambil program Masters of Arts (MA) pada bidang filsafat pada tahun 1899.

${ }^{1}$ Harun Nasution, Pembaharuan dalam Islam: Sejarah pemikiran dan Gerakan' (Jakarta: Bulan Bintang, 1991), h. 11

2 Didin Saefudin, Pemikiran Modern Islam: Biografi Intelektual 17 Tokoh, (Jakarta: Gramedia Media Sarana, 2003), h. 45 
Pada Universitas ini, Iqbal juga mendapat bimbingan dari para dosen-dosen filsafat terkemuka, diantaranya adalah James Wart dan J.E Mac Tegart, seorang Neo-Hegelian, di mana Iqbal juga mengambil kuliah hukum dan ilmu politik di Lincoln Inn London dan berhasil lulus ujian keadvokatan dan memperoleh gelar M.A. Dua tahun kemudian, yakni pada tahun 1907 pindah ke Jerman dan masuk ke Universitas Munich, di Universitas ini ia mendapatkan gelar Ph. D (Doktor) dalam bidang filsafat dengan tesis berjudul "The Development of Metaphysics in Persia" (Perkembangan Metafisika Persia). ${ }^{3}$ Selain itu beliau juga memberi ceramah-ceramah politik dan ceramah-ceramah di Universitas Hyderabad, Madras, dan Aligarh. Hasil ceramah-ceramahnya kemudian dibukukan dengan judul Six Lectures On The Reconstruction Of Religious Thought In Islam, dan edisi berikutnya The Reconstruction Of Religious Thought In Islam, merupakan suatu karya terbesar Iqbal dalam bidang filsafat. ${ }^{4}$ Namun ada suatu peristiwa penting dalam hidup Muhammad Iqbal, yakni terciptanya sebuah karya buku dengan judul "Asrar-i Khudi" pada tahun 1915, yang berisikan ajaran-ajaran tentang ego, dan perjuangan hidup. Uraian yang ada di dalam buku tersebut berbentuk prosa puistik yang sarat akan makna dan kandungan nilai-nilai. Buku tersebut sempat menimbulkan kegemparan di kalangan Pseudo-Mistik yang dalam hidupnya lebih memilih untuk bersikap dalam kehidupan menyendiri. Tak lama kemudian terbit pula karya Iqbal dengan judul buku "Rumuz-I BeKbudi" di tahun 1918 yang berisi tentang ajaran-ajaran kehidupan

Keistimewaan dari Muhammad Iqbal yang luar biasa adalah pandangannya tentang dasar kebudayaan Barat modern dan Islam yaitu bahwa Iqbal tidak menganggap salah bila dunia Islam saat ini sedang mengikuti kebudayaan Barat dengan cepat. Pada sisi intelektual, kebudayaan Barat adalah merupakan perluasan dari fase-fase kejayaan kebudayaan Islam pada masa terdahulu. Yang menjadi kegelisahan seorang Iqbal adalah apabila kejayaan Barat akan mempengaruhi gerakan Islam sehingga menyebabkan penyelewengan kebudayaan yang sebenarnya.5 Pemikirannya mengenai kemunduran dan kemajuan umat Islam mempunyai pengaruh pada gerakan pembaharuan dalam Islam. Sama dengan pembaharu-pembaharu lain, beliau berpendapat bahwa kemunduran umat Islam selama 500 tahun terakhir disebabkan oleh kebekuan dalam pemikiran. Hukum dalam Islam telah sampai pada keadaan statis. Kaum konservatif dalam Islam berpendapat bahwa rasionalisme yang ditimbulkan golongan muktazilah akan membawa pada disintegrasi dan dengan demikian berbahaya bagi kestabilan Islam sebagai kesatuan politik.

Dari beberapa karya Iqbal salah satunya adalah tentang Khudi tentunya akan menjadi babak baru dalam proses pembaharuan dalam Islam masa itu, yang nantinya dapat di kontekstualisasikan dalam pendidikan saat ini, terutama dalam pendidikan di madrasah.

${ }^{3}$ D.G. Adian, Mubammad Iqbal: Seri Tokoh Filsafat, (Jakarta Selatan: Teraju, 2003), h. 96.

${ }^{4}$ Ibid. h. 46

${ }^{5}$ Asif Iqbal Khan, Agama Filsafat, Seni dalam Pemikiran Iqbal, (Yogyakarta: Fajar Pustaka Baru, 2002), h. 3 
Realitas di madrasah sekarang membutuhkan pengembangan kreatifitas dalam melaksanakan proses pembelajaran. Di era milenial peserta didik telah melaju jauh dalam penggunaan gadget dan media sosial lainnya, hal ini menjadi salah satu tantangan tersendiri bagi seorang pendidik dalam menyuguhkan metode yang sesuai dengan keadaan peserta didik saat ini. Secara umum pendidik dapat diartikan sebagai orang yang memiliki tanggungjawab mendidik. Secara khusus, pendidik dapat diartikan sebagai orang yang bertanggungjawab terhadap perkembangan peserta didik dengan mengupayakan perkembangan seluruh potensinya, baik potensi afektif, kognitif, dan psikomotorik. ${ }^{6}$ Dengan kata lain seorang pendidik harus mampu meyelami dan mengikuti perkembangan yang dialami oleh peserta didik.

Dari pemaparan di atas, peneliiti merasa tertarik untuk mengontekstualisasikan konsep Khudi dari seorang Muhammad Iqbal dalam pengembangan kreatifitas pembelajaran di Madrasah. peneliti akan mencoba mengawali menelaah biografi dan sejarah pendidikan yang didapat Muhammad Iqbal, konsep Khudi serta pengembangan konsep Khudi tersebut dalam pembelajaran di Madrasah.

\section{METODE PENELITIAN}

Metode penelitian yang digunakan adalah metode studi pustaka (library research). Studi kepustakaan adalah tekhnik pengumpulan dataddengan mengadakan studi penelaahan terhadap buku-buku, literatur-literatur, catatan-catatan dan laporan-laporan yang ada hubungannya dengan masalah yang dipecahkan. ${ }^{7}$ Jenis penelitian ini adalah termasuk penelitian kualitatif, yaitu penelitian yang menghasilkan informasi berupa catatan dan data deskriptif yang terdapat di dalam teks yang di teliti. bertujuan untuk menggali, mengetahui berbagai pemikiran Muhammad Iqbal dan berbagai karya monumental yang telah ditorehkannya. Subjek penelitian ini adalah tentang konsep Khudi Muhammad Iqbal. Peneliti akan menjabarkan bagaimana konsep Khudi Muhammad Iqbal serta penerapannya dalam pendidikan Islam. Yang terpenting adalah penerapan Khudi Iqbal sebagai motor penggerak kreatifitas pendidik dalam pembelajaran di madrasah. Banyak kajian yang telah disampaikan dalam bentuk tulisan tentang Khudi/ego/konsep diri Iqbal. Beliau merupakan seorang filusuf sekaligus penyair yang memberikan sumbangsih terhadap perkembangan pemikiran Islam modern terutama dalam penelitian ini adalah konsep tentang Khudi. Sudah tentu pemikiran tokoh tersebut mengundang perhatian para peneliti untuk mengkajinya.

${ }^{6}$ Ahmad Tafsir, Ilmu Pendidikan Dalam Perspektif Islam, (Bandung: Remaja Rosdakarya, 1992), h. 74

${ }^{7}$ M. Nazir, Metode penelitian, 1998. h.111 


\section{HASIL DAN PEMBAHASAN}

\section{Konsep Khudi Dalam Pengembangan Kreatifitas Pembelajaran Di Madrasah}

Sebagai seorang yang terkenal nama dan karyanya sampai saat sekarang ini, Iqbal mempunyai faktor penting yang mendukung dan menciptakan kepribadian dan pemikirannya. Pendidikan yang telah memberikan semangat yang hebat di dalam hati dan pikirannya adalah lewat pendidikan yang diperolehnya di Government College, Lahore, yaitu sebuah lembaga yang dirintis oleh para pemikir, ahli hukum, teolog dan mujaddid. Pendidikan yang diberikan lembaga ini tidak terlepas dari penanaman nilai-nilai ruhani. ${ }^{8}$

Saat melakukan pengembaraan pendidikan di Barat secara tidak langsung memberikan latihan dalam melaksanakan proses berfilsafatnya. Hingga awal mula proses berfilsafatnya adalah keyakinan tentang keteguhannya terhadap tauhid keesaan Illahi, serta Tuhan lah yang menjadikan asas keruhaniahan terakhir dalam merealisasikan cita-citanya.

Dalam berbagai makalah banyak ditulis mengenai seorang Iqbal. Di Lahore, terbit sebuah majalah dengan nama Iqbal, yang menerbitkan tentang makalah-makalah, baik dalam bahasa Inggris maupun dalam bahasa Urdu, yakni mengenai filsafat dan sajak-sajak Iqbal. Diantara makalah-makalah tersebut, yang antara lain mengenai: "Evolusi Dalam Filsafat Iqbal", "Seni Menurut Aliran Iqbal", "Iblis Menurut Konsepsi Iqbal", "Filsafat Kepribadian Menurut Iqnbal", "Iqbal Dan Masalah Ijtihad", "Makna Cinta Dalam Sajak Iqbal”, dan "Makna Kemiskinan Dalam Sajak Iqbal".?

Kebesaran nama seorang Muhammad Iqbal sangat berpengaruh pada penikmat karyakaryanya. Hal ini dibuktikan pasca wafatnya telah muncul "Masyarakat Iqbal" (Iqbal Society : sebuah perkumpulan yang aktif mendiskusikan segala sesuatu mengenai Iqbal, baik kepribadian maupun karya dan pemikirannya) ${ }^{10}$, serta telah banyak buku yang disusun baik berbahas Inggris ataupun berbahasa Urdu yang kurang lebih mencapai empat puluh buah buku. Muhammad Iqbal merupakan orang yang sangat produktif, dapat dilihat dari berbagai karyanya yang digunakan untuk mengekspresikan gagasannya, ditulis dalam berbagai macam bahasa mulai dari Inggris, Arab, ada pula yang menggunakan bahasa Urdu dan Persia, telah banyak karya Iqbal yang sudah disulih bahasakan. Hal ini menandai bahwa kompetensi Iqbal dalam berbahasa tidak perlu diragukan lagi.

Selama ini karya dan tulisan Iqbal lebih dikenal banyak yang bercorak sastra daripada filsafat, namun yang menarik disini adalah dari bentuk karya sastra tersebut sesungguhnya terdapat pemikiran-pemikiran filasafatnya. Karya Iqbal sangat banyak dan berfariasi, baik dalam bentuk prosa, puisi, surat-surat jawaban pada orang lain yang mengkritiknya atas

\footnotetext{
${ }^{8}$ HM. Suyibno, Percikan Kegeniusan DR. Sir Mubammad Iqbal, (Jakarta: In Tegrita Press, 1985), h. 23

${ }^{9}$ Abdul Wahab Azzam, Filsafat dan Puisi Iqbal (Bandung: Pustaka, 1985), h. 116-117

${ }^{10}$ H.A.R. Gibb, Aliran-Aliran Modern dalam Islam, (Jakarta: Pustaka, 1991), h. 104
} 
berbagai konsep dan pengantar untuk karya-karya orang lain. Berikut akan dirinci beberapa dari karya-karya Iqbal: 11

1. The Development of Metaphysics in Persia: A Contribution to The History of Muslim Philosophy, merupakan hasil desertasi Iqbal ketika memperoleh gelar Doctor dari Universitas Munich pada tahun 1908. Berisi tentang sejarah pemikiran keagamaan di Persia sejak Zoroaster hingga sufisme Mullah Hadi dan Sabwazar yang hidup pada abad 18, dari mulai pemikiran keagamaan kuno di Persia hingga yang terakhir merupakan kesinambungan pemikiran Islamis, bagian kedua menjelaskan kebudayaan Barat dan berbagai manifestasinya, dan bagian ketiga menjelaskan tentang munculnya Islam hingga peran Turki dalam Perang Dunia Pertama dan kemenangan Turki dalam perang kemerdekaan dari tekanan Barat.

2. Asrar-I Khudi (Rahasia Pribadi), salah satu karya utama dari Iqbal berbahasa Persia yang berisi tentang ajaran mengenai ego insan tentang bagaimana seseorang dapat meraih predikat Insan Kamil, diterbitkan pada tahun 1915 oleh pengarangnya. Konsep Khudi inilah yang nantinya akan banyak dibahas pada tulisan ini.

3. Rumuг-i BeKhudi (Rahasia Peniadaan Diri), buku ini merupakan lanjutan dari pemikiran mengenai Insan Kamil, juga berbahasa Persia. Isi pokok dari buku ini adalah mengenai keberadaan Insan Kamil yang harus bekerja sama dengan pribadi-pribadi lain untuk mewujudkan kerajaan Tuhan di Bumi. Jika Insan Kamil hidup menyendiri, tenaganya suatu waktu akan sirna menurutnya. Buku ini terbit pada tahun 1918 di Lahore.

4. The Reconstruction of Religious Thought in Islam, merupakan tulisan terbesar dari Iqbal dalam bidang filsafat dan berbentuk prosa. Buku ini terbit di London pada tahun 1934. Isi dari buku ini ada tujuh bagian, yaitu: 1) pengalaman dan pengetahuan keagamaan, 2) pembuktian secara filosofis mengenai pengalaman keagamaan, 3) konsepsi tentang Tuhan dan makna sembahyang, 4) tentang ego insani, kemerdekaan dan keabadiannya, 5) jiwa kebudayaan Islam, 6) prinsip gerakan dalam struktur Islam, dan 7) bahwa agama itu bukan sekedar mungkin, tetapi pasti ada sebagai kritik terhadap Hegel, seorang filusuf besar idealisme Jerman.

5. Javid Nama, tulisan berbahasa Persia ini terbit pada tahun 1932 di Lahore. Buku ini menjelaskan tentang petualangan rohani Iqbal ke berbagai daerah. Saat berpetualang itulah Iqbal mengadakan dialog dengan para pemikir, sufi filusuf, politikus maupun pahlawan yang ada pada masing-masing daerah yang disinggahinya. Pada akhir buku ini dituliskan pesan-pesan kepada anaknya Javed Namah dan segenap generasi-generasi baru yang akan muncul pada periode berikutnya. Dan masih banyak lagi karya dari Iqbal yang 
tidak dapat kami sampaikan dalam tulisan ini baik yang berbentuk Puisi, Prosa, suratsurat atau jawaban dari kritik orang lain.

Individu, ego, pribadi atau Khudi adalah bagian terpenting dalam filsafat Iqbal. Filsafat Khudi-nya merupakan sebuah dasar yang menjadi penopang gagasan-gagasannya dan menjadi landasan bagi seluruh konstruksi pemikirannya. ${ }^{12}$ Khudi banyak dibahas dalam karya Iqbal yang berjudul Asra-i Khudi dalam bahasa Persia dan dikembangkan dalam bentuk puisi dan dalam kumpulan ceramah yang kemudian dibukukan dengan judul The Reconstruction of Religious Thought in Islam. Khudi secara harfiah berarti ego atau self atau individualitas, yang merupakan sebuah kesatuan yang riil atau nyata yang menjadi pusat dan landasan dari semua kehidupan, dan merupakan suatu iradah kreatif yang terarah secara rasional. Artinya bahwa hidup bukanlah suatu arus tak terbentuk, melainkan suatu prinsip kesatuan yang bersifat mengatur. Iqbal menerangkan bahwa Khudi merupakan pusat dan landasan dari keseluruhan kehidupan. Seperti yang tercantum dalam matsnawinya Asrar-i Khudi. ${ }^{13}$

Iqbal mengatakan bahwa Khudi adalah "The ego attains to freedom by removal of allobstruction in it's way. It is partly free approaching the individual who is most free God In one word, life is an endavour for freedom" (Ego memperoleh kebebasannya dengan menyingkirkan seluruh rintangan yang menghalanginya/ Ego mencapai kebebasannya secara penuh dengan mendekatkan diri kepada Tuhan/ Dengan kata lain, hidup adalah suatu usaha untuk memperoleh kebebasan). Khudi merupakan unsur terpenting dalam masyarakat Islam, karena Khudi merupakan pusat kehidupan dunia. Maju mundurnya suatu bangsa atau masyarakat ditentukan oleh pandangan mereka terhadap Khudi ini.

Iqbal menekankan tentang pentingnya Khudi. Namun demikian Khudi bukanlah suatu anugerah yang bersifat statis, namun bersifat dinamis. Oleh sebab itu seorang manusia harus dapat mengembangkan Khudi-nya melalui tenaga dan usaha yang sinergi, disiplin yang kuat dan tegas pada karakternya. Iqbal juga menegaskan bahwa Khudi merupakan sebuah pusat dan landasan dari kehidupan. Hal ini tercantum dalam matsnawi Asrar-i Khudi sebagai berikut:

The form of existence in an effect of the Self

Whats ever thoe seest is a secret of the Self

When the Self awoke to consciousness

It revealed the universe of Thought

A bundred world are bidden in its essence.

(Bentuk kejadian adalah bentuk dari Khudi, apa saja yang kau lihat ialah rahasia Khudi, bila Khudi bangkit pada kesadaran nyata, dijelmakannya alam cita dan pikiran murni, ratusan alam terlingkung dalam inti sarinya). Dari kutipan matsnawi di atas menurut Iqbal, pribadi

12 K.G. Saiyidain, Iqbal'z, Educational Phylosophy", (terjemahan M.I. Soelaeman). (Bandung: Diponegoro, 1981), h. 11

13 Zulkarnain, Filsafat Khudi Mohammad Iqbal dan Relevansinya Terhadap Masalah Keindonesiaan Kontemporer, (Tesis). (Pascasarjana UIN Sumatra Utara, 2016), h. 45 
sejati adalah bukan yang menguasai alam benda tetapi pribadi yang dilingkupi Tuhan kedalam Khudinya sendiri. Maka sifat dan pikiran pribadi atau Khudi adalah:

1. Tidak terikat oleh ruang sebagaimana halnya dengan tubuh.

2. Hanyalah lanjutan masa mengenai kepribadian.

3. Kepribadian pada asasnya tersendiri dan unik.

Menurut seorang filusuf Barat yaitu Descartes mengemukakan tentang ego. Aktivitas ego menurut Iqbal pada dasarnya bukan semata-mata berfikir seperti yang disampaikan oleh Descartes, akan tetapi berupa aktivitas kehendak seperti tindakan, harapan dan keinginan. Tindakan-tindakan tersebut spontan yang terefleksikan dalam tubuh. Dengan kata lain tubuh adalah tempat penumpukan tindakan-tindakan dan kebiasaan ego.

Ego adalah sesuatu yang dinamis, beliau mengorganisir dirinya berdasarkan waktu dan terbentuk, serta disiplinkan pengalaman sendiri. Setiap jalannya pikiran baik masa lampau atau sekarang adalah jalinan yang tidak terpisahkan dari suatu ego yang mengetahui dan memeras ingatannya. ${ }^{14}$ Esensi watak adalah ego, sebagaimana dalam konsepsi Islam adalah memimpin karena ia bergerak dari amr (perintah) Illahi. Artinya, realitas eksistensi manusia terletak pada sikap keterpimpinan egonya dari sang Illahi melalui pertimbanganpertimbangan, kehendak-kehendak, tujuan-tujuan dan apresiasinya. Oleh karena itu kian jauh jarak seseorang dari Tuhan, maka kian berkuranglah kekuatan egonya. Bagi seorang Iqbal, agama lebih dari sekedar etika yang berfungsi membuat orang dapat lebih terkendali secara moral. Baginya dalam proses evolusi ego manusia dimana etika dan pengendalian diri hanyalah tahap awal dari keseluruhan perkembangan ego manusia yang selalu menginginkan kesempurnaan.

Sebagai seorang individu, manusia adalah suatu kegiatan penciptaan yang terus menerus dari suatu semangat meningkat bergerak ke depan dan naik dari satu keadaan kepada keadaan lain. Manusia harus senantiasa menciptakan perubahan untuk mencapai kemajuan. Oleh sebab itu, manusia harus mengambil inisiatif untuk mengembangkan potensi kekayaan bathinnya. Sebab bila manusia sudah merasa puas dengan keadaannya dan berhenti merasakan desakan internal Khudi-nya untuk bergerak maju, maka semangatya akan membantu dan ia pun terjatuh seperti benda mati. Tujuan Khudi dari Muhammad Iqbal bukanlah membinasakan diri dari batas individualitas, melainkan memberi batasan tentang dirinya yang tegas. Tujuan terakhir Khudi, bukanlah melihat sesuatu, tetapi menjadi sesuatu.

Selanjutnya Khudi Muhammad Iqbal dapat mengarah kepada dua alur dalam rangka proses kebangkitan kaum muslimin menuju perubahan. Jika Khudi diaplikasikan kedalam bidang politik maka yang akan terjadi adalah dinamisme Islam. Sedangkan jika Kbudi diaplikasikan kedalam bidang tasawuf maka akan menyebabkan terbukanya hijab-hijab dalam

${ }^{14}$ D.G. Adian, muhamad Iqbal... h. 78 
aktualisasi diri kepada Tuhan dan sesama manusia. Pengembangan Khudi menurut Iqbal sebisa mungkin untuk mengarah kepada Khuda, Ego Mutlak atau individu yang hakiki, Allah. Tujuannya adalah untuk meningkatkan martabat spiritual Khudi tersebut. Untuk mencapaii sedekat mungkin kepada khuda, individu harus berusaha dan berjuang terus menerus melawan segala bentuk kekuatan kebendaan yang dapat menghambat perkembangan Khudi. Jika berhasil ia akan mendekati kesempurnaan Khudi. ${ }^{15}$ Dalam mencapai kesempurnaan Khudi, ada tiga fase yang harus dilalui, yaitu: kekuatan kepada hukum Illahi, penguasaan diri dan perwakilan Illahi. Menurut Muhammad Iqbal ada beberapa hal yang dapat memperkuat Khudi seseorang, yaitu:

1. Cinta $(I s h q)$

Cinta yang dimaksud disini adalah cinta terhadap harapan dan ideal, membangkitkan kepribadian dan menampak kekuatan-kekuatann yang ada di dalamnya. Seperti idealnya seseorang ketika mencintai Rasulullah SAW. Apabila seseorang dapat mengendalikan cinta, maka tiada lagi penghalang dan kesulitan, dan iapun tidak mempunyai rasa takut dan gentar, serta bisa membuat manusia menaklukkan alam semesta, seperti dalam kutipan syairnya Muhammad Iqbal:

Oleh cinta pribadi kian abadi

Lebih hidup, lebih menyala, dan lebih kemilau

Dari cinta menjelma pancaran wujudnya

Dan perkembangan kemungkinan yang tak diketahui semula

Fitrahnya mengumpul api dari cinta

Cinta mengajarinya menerangi alam semesta

Cinta tak takut pada pedang dan pisau belati

Cinta tidak berasal dari air dan bumi

Cinta menjadikan perang dan damai di dunia

Sumber hidup ialah kilau pedang dunia.

Jika cinta sudah dapat memperkuat ego, maka segala hal yang menjadi penghalang insan untuk dapat mengembangkan potensi dan mengaktualisasikan diri dapat teratasi. Cinta disini merupakan percintaan insan (manusia) kepada Tuhannya, yang mengatasi segala-galanya, bukan cinta jasmani atau pencarian mistik yang samar-samar dan sia-sia saja. Bagi Iqbal, cinta (isyq) disini adalah suatu istilah ddengan pengertian khusus yang memiliki arti "sebuah bentuk usaha pertautan maksimal dari segala potensi yang dimiliki akal dan intuisi." Dengan cinta, ego akan menemukan ego mutlak (Tuhan) yang ia cintai.

Dengan konsep cinta yang seperti itu akan dapat memanusiakan manusia dalam derajat yang sesungguhnya. Karena sejatinya semua ciptaan Tuhan adalah bentuk manifestasi Tuhan itu sendiri. Begitu juga dengan manusia, yang merupakan satu-satunya makhluk yang mendapat amanah besar dari Tuhan untuk memimpin dan memikul dunia. Menurut Iqbal, semakin dekat seseorang kepada Tuhan maka akan semakin mantap

\footnotetext{
${ }_{15}$ M. Iqbal, H. Nasution, Amien Husein, Pembaharuan dalam Islam: Sejarah Pemikiran dan Gerakan (VII), (Jakarta: Bulan Bintang, 1991), h. 11
} 
individualitasnya. Begitu pula sebaliknya, semakin jauh manusia dari Tuhan maka semakin ia kehilangan individualitasnya. Proses pendekatan ini bertujuan untuk menyerap sifat-sifat Tuhan dalam dirinya tanpa harus kehilangan sisi individualitasnya.

2. Faqr

Muhammad Iqbal sangat mendukung sikap hidup seseorang yang aktif dalam menaklukkan materi keduniaan. Akan tetapi memang sulit di era zaman sekarang ini yang setiap manusia berlomba lomba untuk memenuhi hasrat keduaniawian dan sulit untuk mengekang keinginan-keinginan dalam memperbanyak materi. Dikarenakan memang selain tuntutan pemenuhan hidup juga godaan nafsu untuk semakin memperkaya diri.

Oleh karena itu, Iqbal mendambakan agar manusia (walaupun terlibat dalam usaha penguasaan bidang materi) tetap memiliki sikap bebas, tidak terikat, serta mampu mengatasi hasrat untuk memiliki materi secara berlebih-lebihan. Dapat diartikan pula hidup prihatin, namun tidak diartikan prihatin dalam arti sempit dan negative tetapi lebih kepada tidak berlebih-lebihan dalam hal duniawi, secukupnya saja.

Faqir adalah jalan hidupku, bukan berpesta pora

3. Berani

Maka jangan jual Khudimu dengan memakai baju peminta-minta. ${ }^{16}$

Untuk menciptakan insan kamil yang kuat, dalam arti yang sebenarnya, maka Iqbal berkeyakinan tentang perlunya memupuk keberanian. Karena dengan keberanian ini seorang insan tidak akan merasa takut dalam menjunjung tinggi kebenaran, hingga derajat Insan Kamil pun dapat tercapai. Insan yang berani adalah mereka yang sadar bahwa dirinya adalah The Maker of Own Destiny (penentu nasibnya sendiri), sehingga ia dapat menemukan makna hidup dan pengalaman sendiri. ${ }^{17}$

Keberanian merupakan sebuah kekuatan, keberanian dapat dipupuk dan dijadikan salah satu pertanda dari watak dengan menjadikan tauhid sebagai prinsip kerja yang melandasi segala tingkah laku kita. Dan musuh utama dari keberanian adalah takut.

Keberanian akan mengantarkan seseorang pada sebuah pribadi yang tak gentar dalam mencapai setiap yang menjadi sita-cita dalam kehidupannya. Tanpa adanya sebuah keberanian, maka seseorang akan dengan mudahnya terlindas dan tertindas oleh setiap yang ada dalam kehidupannya. Orang yang berani adalah mereka yang sama sekali tidak mengenal putus asa dalam menghadapi setiap cobaan yang memberatkan langkahnya dalam proses mencapai Insan Kamil.

4. Toleransi

Toleransi menurut iqbal adalah sikap menghargai (respek) kepada kebenaran dan cinta akan keinsanan serta tidak menyetujui sikap bersitegang yang berpegang kepada

${ }^{16}$ DJ. Matthews, Iqbal A Selection of The Urdu Verse, (Heritage Publisher, 1993), h. 117.

${ }^{17}$ Didin Saefudin, op.cit. h. 50 
loyalitas dan ajaran-ajaran yang sempit. Tindakan toleransi ini pun juga mendukung proses pendidikan ego seorang insan. Seperti kata Iqbal: "Prinsip dari perbuatan yang mendukung ego ialah menghargai ego dari diri sendiri maupun ego dari orang lain”.

Hasil dari peneliti melakukan telaah terhadap konsep/ gagasan Muhammad Iqbal, bahwa madrasah menjadi salah satu bagian terpenting dalam pendidikan Islam. Madrasah berasal dari bahasa Arab, dari kata dasar "darasa" yang artinya tempat belajar para pelajar, dapat juga diartikan jalan. Kata madrasah juga ditemukan dalam bahasa Hebrew atau Aramy, dari kata dasar "darasa" yang berarti membaca dan belajar atau duduk untuk belajar. Dari kedua bahasa tersebut, kata madrasah mempunyai arti yang serupa, yaitu tempat belajar. Dari akar makna tersebut kemudian berkembang menjadi istilah yang berkonotasi sebagai tempat belajar yang bernuansa Islam. ${ }^{18}$

Salah satu cita-cita umat Islam Indonesia yang sering dikumandangkan para pemimpin umat menjelang kemerdekaan ataupun setelah kemerdekaan adalah kemerdekaan adalah adanya lembaga pendidikan yang mampu menghasilkan calon ulama. Dengan istilah lain, madrasah diharapkan menyiapkan anak didik yang dapat memadukan iptek dan imtaq. Melalui SK-SK Mendikbud, yang ditegaskan dengan SK-SK Kementerian Agama, maka MI, MTs, dan MA wajib memberikan bahan sekurang-kurangnya sama dengan SD, SLTP, dan SMA untuk mata pelajaran umum dan menambahkan pelajaran agama. Implikasinya, madrasaha sama dengan sekolah umum yang berciri khas Islam. Perubahan ini disatu sisi memang merupakan perubahan yang menggembirakan. Lulusan madrasah menjadi setara dengan lulusan sekolah umum yang setingkat. Namun disisi lain, justru menjadi prersoalan tersendiri bagi madrasah, diantaranya: a) berkurangnya muatan materi pendidikan agama dapat dilihat dari pendangkalan pemahaman agama. muatan kurikulum sebelum SKB saja dirasa belum mampu mencetetak muslim sejati, apalagi kemudian dikurangi. b) Lulusan madrasah serba tanggung. Pengetahuan agamanya tidak mendalam sedangkan pengetahuan umumnya juga rendah. Madrasah sebagai lembaga pendidikan Islam yang hidup dari, oleh dan untuk masyarakat muslim, belum mampu melahirkan generasi-generasi muda Islam yang mampu menjawab tantangan zaman. Bahkan lebih memprihatinkan lagi tamatan madrasah masih dipandang mempunyai prestasi yang rendah.

Beberapa persoalan diatas menjadi sebuah tantangan tersendiri bagi sebuah madrasah, terlebih kepada para pendidik. Seorang pendidik dituntut agar dapat menghantarkan peserta didik menjadi agen perubahan di masyarakat pasca mengenyam pendidikan di madrasah. Dengan beberapa keterbatasan diatas seorang pendidik harus berupaya meningkatkan kapasitas dirinya untuk dapat mengimbangi siswa dalam melakukan proses pendidikan.

\footnotetext{
${ }^{18}$ Khoirul Huda, Problematika Madrasah Dalam Meningkatkan Mutu Pendidikan Islam, Journal of Dinamika Penelitian Vol (16). 2016, h. 6
} 
Jangan sampai seorang pendidik tidak siap, bahkan terlihat kuno di mata siswa dalam melakukan transfer ilmu.

Sejalan dengan berbagai persoalan tersebut di atas terkait dengan konsep Khudi Muhammad Iqbal menjadikan pendorong bagi para pendidik dalam meningkatkan kreatifitas dalam melaksanakan ketugasan di madrasah. Beberapa konsep Khudi dalam menumbuhkan kreatifitas di madrasah dari seorang Iqbal, diantaranya adalah:

1. Dalam konsep Khudi Iqbal, sebagai seorang pendidik diharapkan dapat memahami bahwa realitas kehidupan ini tidak hanya semata mata sebagai kehendak Tuhan saja, namun lebih pada pilihannya sendiri. Dengan konsep ini diharapkan seorang pendidik dalam melakukan proses pendidikan akan lebih terarah dan tidak pasif/monoton sehingga selalu meningkatkan kreatifitas dalam melakukan pengajaran.

2. Insan kamil menjadi sebuah tujuan yang akan ditempuh bagi seorang pendidik dalam mengantarkan peserta didik agar mampu menghadapi masa depan yang baik, di dunia maupun dia khirat. Seorang pendidik yang sejati dalam pendidikan antara harapan dan kerja, perbaikan dan pembinaan, perdamaian dan keserasian, tidak menjadi lemah karena adanya halangan dan tidak menjauhi kesukaran.

3. Untuk mencapai sebuah pendidikan yang terarah dan kritis, seorang pendidik harus berupaya bergerak pada satu arah dan tujuan. Aktivitas kreatif dan perjuangan tanpa henti dalam menghadapi permasalahan pendidikan harus menjadi sebuah tujuan hidup. Dengan sikap kreatif itulah nantinya manusia akan dapat mengubah dan menggubah sesuatu yang belum tergarap dan terselesaikan dan mengisinya dengan aturan dan keindahan.

4. Seorang pendidik diharapkan mampu mendidik peserta didik agar memiliki keberdayaan diri dalam bentuk sumber daya manusia, yang dapat teraktualisasikan dan terarahkan pada kreasi yang konstruktifi.

5. Pendidikan di madrasah membutuhkan suntikan ide-ide baru agar ruh keislaman tidak luntur, meski dengan aturan ataupun kebijakan baru. Karena pendidikan Islam adalah bagian yang tidak tepisahkan dari ajaran Islam secara keseluruhan. Pada akhir tujuannya adalah agar selaras dengantujuan hidup dalam Islam, karena tujuan hidup seorang muslim juga menjadi tujuan akhir sebuah pendidikan Islam.

6. Konsep Khudi menekankan pada setiap aspek pengampu pendidikan Islam di madrasah tidak hanya meiliki nilai watak dan kreatifitas saja, namun lebih tinggi lagi adalah menerapkan pendidikan dengan adanya saling menghargai, saling menghormati, saling kerjasama dan penuh toleransi diantara pelaku pendidikan. 


\section{SIMPULAN}

Muhammad Iqbal merupakan legenda ahli dari segala bidang. Merupakan penyambung antara kebudayaan Barat dan Timur, ditengah gencaran pembaharuan pada masanya. Iqbal seolah menjadi pelepas dahaga ditengah keterpurukan umat muslim, dengan gagasan-gagasan yang mensintesiskan antara Barat dan Timur, menjadi gagasan yang unik yang dapat melampaui masanya. Gagasan Iqbal yang ingin merekonstruksi pendidikan Islam dan keadaan umat muslim pada waktu itu, ditengarai oleh ketidakpuasannya melihat kejumhudan umat muslim, disisi lain Iqbal merasa muak dengan kemajuan yang diraih oleh Barat. Rekonstruksi yang ditawarkan Iqbal tidak melepaskan aspek ukhrawi untuk duniawi, ataupun sebaliknya, melainkan harus saling melengkapi dan mampu untuk berdialog satu sama lain. Agar tecipta dinamisme dalam kehidupan, yang mana semua itu dapat dicapai dengan konsep yang digaungkan oleh Iqbal yaitu Khudi.

Individu, ego, pribadi atau Khudi adalah bagian terpenting dalam filsafat Iqbal. Filsafat Khudi-nya merupakan dasar penopang gagasan dan menjadi landasan bagi seluruh konstruksi pemikirannya. Khudi merupakan proses pencarian potensi luar biasa dalam diri, yang dalam hal ini Iqbal mengemas energi luar biasa kedalam syair dan sajak-sajaknya. Ego mencapai kebebasannya secara penuh dengan mendekatkan diri pada Tuhan.

Berbagai permasalahan yang timbul dalam dunia pendidikan terutama di madrasah tentunya dapat terselesaikan dengan konsep pemikiran Khudi-nya Iqbal apabila benar-benar diaktualisasikan dengan tepat dan bisa menjadi nilai tawar sebuah pemecahan masalah yang selama ini ada dalam pendidikan di madrasah. Konsep dalam yang ditawarkan oleh Iqbal salah satunya adalah perlunya keberanian dan semangat pendidik yang sedemikian rupa dalam mengolah rasa saat menghadapi peserta didik sehingga dapat terwujud interaksi sosial yang baik.

\section{DAFTAR PUSTAKA}

Adian, D. G. Muhammad Iqbal: Seri Tokoh Filasafat. cetakan 1. Jakarta: Teraju. 2003.

Azzam, A. W. Filsafat dan Puisi Iqbal. Bandung: Pustaka. 1985.

Faizin, A. Ubermensch dan Al Insan Kamil. Skripsi. IAIN Sunan Ampel. 2006.

Gibb, H. A. R. Aliran-Aliran Modern dalam Islam . Jakarta: Pustaka. 1991.

Huda, K. Problematika Madrasah Dalam Meningkatkan Mutu Pendidikan Islam. Journal of Dinamika Penelitian. (16) 6. 2016.

Khan, A. I. Agama, Filsafat, Seni Dalam Pemikiran Iqbal. Yogyakarta: Fajar Pustaka Baru. 2002.

Nazir. M. Metode penelitian. Jakarta: Ghalia Indonesia. 1998. 
Matthews, D. , Iqbal A Selection Of The Urdu Verse. India: Heritage Publisher. 1993.

Nasution, H. , Pembaharuan dalam Islam: Sejarah Pemikiran dan Gerakan (VIII). Jakarta: Bulan Bintang. 1991.

Nasution, M. I. dan A. H., Pemikiran Politik Islam. Jakarta: Kencana. 2013.

Saefudin, D. Pemikiran Modern Islam: Biografi Intelektual 17 Tokoh. Jakarta: Gramedia Widia Sarana. 2003.

Saiyidain, K. Iqbal'z Educational Philosophy terjemahan M.I. Soelaeman. Bandung: Diponegoro. 1981.

Suyibno, H. Percikan Kegeniusan DR. Sir Mubammad Iqbal. Jakarta. In Tegrita Press. 1985.

Tafsir, A. Ilmu Pendidikan dalam Perspektif Islam. Bandung: Remaja Rosda Karya. 1992.

Zulkarnain. Filsafat Khudi Mohammad Iqbal dan Relevansinya Terhadap Masalah Keindonesiaan Kontemporer. Pascasarjana UIN Sumatera Utara. 2010. 